\title{
THE BRICS, A POST-HEGEMONIC MODEL WITH ITS OWN NORMATIVITY: HOW DO THE BRICS REACH TO INFLUENCE WTO LAW THROUGH THE ORIENTED USE OF WHO POLICIES?
}

\author{
OS BRICS, UM MODELO PÓS-HEGEMÔNICO COM A SUA PRÓPRIA NORMATIVIDADE: \\ ANÁLISE DO USO DAS NORMAS DA OMS PARA INFLUENCIAR O DIREITO DA OMC
}

Meryl Thiel ${ }^{1}$

\begin{abstract}
In response to Krasner's view, exclusively focused on geopolitical tensions and power games on the world stage, Keohane's counter-multilateralism approach brings a solution: that of cooperation. The fact remains that the explanation delivered by international relations overlooks the fundamental role of law. Currently, the BRICS legal policy presents itself as a paradigmatic model, which shows how Krasner's and Keohane's theories complement one another, thanks to their targeted use of international law. This paper aims to demonstrate that the BRICS - in defining an innovative and independent legal policy influence normativity processes - are a post-hegemonic construction, with their own normativity, intended to fight against the organized hypocrisy of our international system. In view of the question of how the BRICS participate in the moralization of capitalism, I have considered the hypothesis of a BRICS hegemony, in the sense that the forms of cooperation promoted by the group are innovative and are not corresponding to any concept currently in force: the group uses WTO and WHO's health policies to curb world trade regulations. The main idea of this paper is to try to articulate the international relations theories with a legal analysis. In other words, my working assumption is that to be able to design its own normativity, the group diverts the WTO's political and legal mechanisms, via the WHO's health requirements, and is, therefore, rising as a new hegemonic formation.
\end{abstract}

Keywords: Normativity; WTO; WHO; BRICS; Shift Focus; Counter-Multilateralism.

\section{Resumo}

Em resposta à visão de Krasner, focada exclusivamente em tensões geopolíticas e jogos de poder no cenário mundial, a abordagem do contra multilateralismo de Keohane traz uma solução: a cooperação. Agora a explicação fornecida pelas relações internacionais desconsidera o direito como guardião da arquitetura do sistema internacional. Atualmente, a política jurídica do BRICS apresenta-se como um modelo paradigmático que mostra como as teorias de Krasner e Keohane se complementam, graças ao uso direcionado do direito internacional. Este artigo pretende demonstrar que os BRICS - na definição de uma política jurídica inovadora e independente - influenciam os processos normativos. Argumento que os BRICS são uma construção pós-hegemônica, com normatividade própria, destinada a combater a hipocrisia organizada de nosso sistema internacional. Considero os BRICS como uma forma de cooperação inovadora que não corresponde a nenhum conceito atualmente em vigor: o grupo usa as políticas de saúde da OMC e da OMS para conter as regulamentações do comércio mundial. A ideia

\footnotetext{
${ }_{1}^{1}$ Associate Researcher in Sciences Po Aix-en-provence, France. ORCID: https://orcid.org/0000-00026574-6191. E-mail: m.thiel@live.fr.
} 
principal deste trabalho é tentar articular as teorias das relações internacionais com uma análise jurídica. Em outras palavras, a minha hipótese é que, para ser capaz de projetar sua própria normatividade, o grupo desvia os mecanismos políticos e legais da OMC, por meio dos requisitos de saúde da OMS, e está, portanto, surgindo como uma nova formação hegemônica.

Palavras-Chave: Normatividade; OMC; OMS; BRICS; Shift Focus; Contra Multilateralismo.

\section{INTRODUCTION: THE URGENT NECESSITY TO RECONSIDER HEGEMONY}

Between nationalisation and neo-colonisation, the issue of hegemony - ever since Gramsci - has fuelled the debate on international relations. This leads us to argue that international economic relations do not only derive from the guiding principles of States, nor are they solely determined by the dynamics of capital. Power has become a central issue, and we are gradually shifting from a restrictive approach to a softer one, based on Keohane and Nye's model (2001). Since the 1990s, the intelligentsia has largely questioned the State's deconstruction, and the decline of State-centrism has pointed towards more democratic governance in the 21st century (HAGGARD; SIMMONS, 1987). The United States, as the ultimate victor of WW2, were able to influence modern-day international relations, to build a form of hegemony tacitly accepted by all (KEYLOR, 2003). So, although the concept of hegemonic power is not, per se, necessarily malevolent, the abuse of dominant position certainly is. The paradox of this undeniably multipolar projection is that, at the same time, the 2000s have shown the scale of international dis(order) due to all-too-long accepted US dominance (GRAY; MURPHY, 2013). Yet today, can we still assert that State and Power are synonymous?

A hegemon is ontologically a guide and, as specified inter alia by Gilpin, it is supposed to ensure the provision of several goods, including access to health, because this serves its own interests and goals of power (KOHLMORGEN, 2007). Hegemony describes how a dominant power sets out the premises of a desirable order in universal terms and presents them as a system that benefits everyone (KINDLEBERGER,1981). Conversely, according to Cox (1983), hegemony is formalised within a set of standards, institutions and universal procedures, which lay down the basic rules of behaviour applicable to States, as well as transnational social forces; sort of guiding principles that support the dominant mode of production. The analyses of both Gramsci and Hirschman reconcile these two approaches and shine a light on the BRICS reality, in so far as it addresses the issue of regional hegemony. In the face of an ever-changing international society, the BRICS model of alternative cooperation illustrates this new manner of developing a world society, away from North-South, South-South and East-West approaches or 
even from the allegedly 'universal' ones of international organizations (IOs) (WEBB; KRASNER, 1989).

With the subprime crisis, IOs have undoubtedly been overwhelmed by the world society's intricate interdependencies and interactions and with the BRICS nations, it is the very perception of relations between regionalism and multilateralism that has changed radically (ACHARYA, 2004). Although the acronym was coined by Goldman Sachs in 2001, the BRICS model itself only emerged five years later, through the commitment of the States concerned. Considered as a genuine institutional innovation, the BRICS rest upon no legal ties, and are rather the result of a voluntary association of States through the pooling of their interests to conduct balanced international trade relations. By definition, the BRICS nations are not an IO and are also decidedly different from a regional organization: they are, by nature, geared only toward cooperation, rather than integration. As their initial financial objective was rapidly exceeded, the BRICS are now a sound co-operative entity, grouped around world trade regulatory issues, which illustrates the need of genuine counter-multilateralism to cope with hegemonic abuses and, more broadly, modern legal frameworks' lack of efficiency in meeting the emerging needs of our societies (SHRADDHA, 2016; KEOHANE and MORSE, 2013). In addition to the present state of international law, there is another aspect to be considered: the BRICS national economies have to solve a similar entanglement: Their will to be major players within international trade comes up against significant national health challenges (SILVA, 2014). The group's four main members are experiencing problems related to,

1. the health protection of their citizens in the absence of adequate funding mechanisms;

2. the spread of infectious diseases;

3. drugs.

No doubt that the BRICS are a pioneering force: their institutional uniqueness and substantial innovation are redefining the governance model (NOGUEIRA, 2012), but how can the BRICS legitimately uphold these three common issues? Their legitimacy is based on fulfilling their commitments, in a political sense. It is, after all, through the strength of their actions and decision-making that the BRICS will have a lasting impact on the world stage. The group's final goal remains to 'contribute to a fairer world trade' but, considering that the interplay of power within the WTO is almost impossible to outflank in the event of direct action, the BRICS will bypass the problem raised by Krasner (2004), and thus fully illustrate the counter-multilateralism model, in the vein of Keohane's regime shifting model(KEOHANE and MORSE, 2013).

The challenge of health policy compliance is fundamental for the group as a whole, since each State has strong national interests in solving its public health issues (KOHLMORGEN, 2007). 
Incidentally, such issues are part and parcel of trade policy regulations. Indeed, public health concerns within world trade development have been included in the WTO agreements since the Uruguay Round negotiations (OMS, OMC, 2002). As a result, as much the TRIPS, the GATS, as some of the trade-in goods agreements provide for exceptions to the Organization's rules when it comes to complying with several health requirements. The WTO's interpretation of the WHO's principles is worth noting in two areas: the protection of living species through the adoption of trade measures, which avoid causing them harm; and support for the recognition of intellectual property rights that guarantee the proper use of natural resources and/or the protection of said resources and species. Yet, the inclusion of provisions related to the protection of public health within WTO agreements - although 'universal' - has proved to be insufficient from 2001, at least as evidenced by the Doha Development Agenda. It seems that the WTO's texts are too vague to satisfy the WHO's expectations. It appears that the financial and technical support driven by WTO-WHO institutional cooperation is more of a palliative than an offer of tangible aid. Against this backdrop, and guided by a substantial twofold benefit, the BRICS nations will define themselves as those who transform economic growth into better health. They will first boost funding policy, combined with reinforcement of technology, as well as a transformative change in institutional cooperation and technical support, acting simultaneously within the WHO and the WTO.

In response to Krasner's view, exclusively focused on geopolitical tensions and power games on the world stage, Keohane's counter-multilateralism approach brings a solution: that of a genuine cooperation. Indeed, although the WHO and the WTO move towards institutional and legal cooperation, their commitments seem to be insufficient to meet the BRICS needs. Although now the traditional fora of international law are no longer the only ones that can claim hegemonic practices, the fact remains that the explanation delivered by international relations overlooks the fundamental role of law, as the custodian of the international system's architecture. Currently, the BRICS legal policy presents itself as a paradigmatic model, which shows how Krasner's and Keohane's theories complement one another thanks to their targeted use of international law. Given the indisputable decline of the efficiency and, by extension, the legitimacy of classical IOs, and considering that the BRICS, following the announcement of the creation of the New Development Bank in 2014, are now seen as a genuine alternative to existing power relations, the question then arises: how does the group achieve its original purpose of a 'fairer world trade'? In other words, and to factor in a more legal analysis - unfortunately all-too-often overlooked one needs to determine whether there is a normativity inherent to the BRICS. My working assumption is that to be able to design its own normativity, the group diverts the WTO's political and legal mechanisms, via the WHO's health requirements, and is, therefore, rising as a new 
hegemonic formation. The BRICS will turn their weaknesses in the health field into an asset to permeate world trade law, by developing a tripartite legal policy focused on national health policy reform:

1. set up a national health-insurance system for their citizens;

2. fund new technologies to eradicate the most lethal infectious diseases;

3. fight against drugs, including tobacco, through monitoring schemes and information campaigns.

This paper aims to demonstrate that the BRICS - in defining an innovative and independent legal policy - influence normativity processes. Based on the counter-multilateralism model, we current IOs are losing their legitimacy while the BRICS logic opens new pathways and setting up a shift focus (KEOHANE and MORSE, 2013). Soon after defining this sectorial pathway, the group will acquire a certain legitimacy, and operates a shift focus, using the vital topic of international health. As a knock-on effect, it has an impact on WTO law: the instrumentalization of WHO's health policies to curb world trade regulations seems to be the only way for the BRICS to meet their goal of a 'fairer world trade'. Doing it so, the group will increase its legitimacy on the world stage (CASHWELL, 2014). Indeed, while recognising the crucial existence of WHO and WTO, the BRICS nations are defining a normative framework for and by themselves, demonstrating the ineffectiveness of the classical subjects of law and how useless they are for current international relations.

We argue that the BRICS are a post-hegemonic construction, with their own normativity, intended to fight against the organized hypocrisy of our international structure, such as Krasner qualified the international system. The BRICS pathways consist of defining a threefold sectorial and legal policy modelled on the WHO's requirements and their own domestic interests (KEOHANE, 1989 and 2002; KRASNER, 2001). By using 'fuzzy law', the BRICS will strengthen their commitment to enshrine health policies in international trade practices (I), but it is with the optimisation of soft law that they will contribute to the creation of a genuine right to participate (II), whereby each member State may defend its interests without having to submit other members to their own will (KEOHANE and MILNER, 1996; KRASNER, 1985 and 2001).

\section{THE IMPLEMENTATION OF FUZZY LAW: CONSTRUCTION OF A PRE-NORMATIVITY BY THE BRICS ENGAGEMENT}

In a world dominated by the opposition between hard law / soft law, the BRICS inversely acts upon this duality by translating its political interest into a sort of fuzzy law. This concept 
presents itself as an alternative of quasi-legality allowing to better consider the creative dynamics of the relations between law and politics (PEREZ, 2015). Fuzzy law is a proper legal qualification of the legal policy practices of non-subjects of international law. Kind of pre-soft law, the fuzzy integrates the vague and random dimension of contemporary international law considering the normativity of the pre-juridical acts.

Separating itself from the strict obligation approach in order to make political law prevails, BRICS sets the scene for what became later the prelude of soft power and they elaborated on the modes of its right to participate in the international system. The use of fuzzy law is important in our study as it helps to understand the positioning of the BRICS vis-à-vis the ongoing failing IOs and, more importantly, it helps to give sense to the development of its health policy integration strategy to world trade practices. Indeed, the BRICS lays the groundwork for its necessity even before the drafting of legal acts. It is therefore through its active engagement that the BRICS will ensure its breakthrough as an indispensable player in the renewal of international law. Fuzzy law, or law of elaboration, as used by BRICS, translates action into diplomacy, swinging between structuring at an international level (A) and acting by transgression on the current global order through the creation of its own global legal entities (B).

\subsection{THE BRICS STRUCTURING ACTION BY ARTICULATING THE PROMOTION OF NATIONAL FUNDING, R\&D AND CLAIMING INTELLECTUAL PROPERTY RIGHTS AT AN INTERNATIONAL LEVEL}

In her speech at the first meeting of the BRICS Health Ministers, the WHO DG Stated:

I am personally convinced that the BRICS countries are the ground on which the real impact of the diseases will be demonstrated. (...) I also believe that the economic cost of these diseases may be such that it negates the so-called benefits of modernization and economic growth. (ACHARYA, 2014).

In response, the Beijing declaration focused on the cardinal health-trade relationship for the Group and set out its ambition to fight infectious diseases. To implement this broad objective, each BRICS member has developed a national policy for financing research and development in the health sector and more specifically on the prevention aspect, thus becoming a vital vaccine producer. Instead of funding medicines in the strictest sense of the word, or initiating legal actions before the Dispute Settlement Body (DSB), the national BRICS allegations are based on the violation of the TRIPS, and the BRICS States opted for a prevention policy, competing against superpowers, especially the United States, since the beginning: yet the bias is to have a larger production of made in BRICS vaccines, and, therefore, a higher number of patents for these 
countries (YU, 2008; BARTSCH, 2007). The BRICS preventive strategy, which makes BRICS be a post-hegemonic power, is to divert the current institutions and not to oppose to the powers already established. In this way, the group ensures:

1. a constant and consistent financial benefit and is, therefore, an alternative to the traditional mechanisms of international financing;

2. an increase in patent rights and therefore the assertion of its power within the WTO and more broadly in world trade;

3. a certain legitimacy both on the international scene and on the part of civil society BRICS.

Power games as presented by Krasner invite indeed to avoid confrontation in favour of cooperation. But, as Keohane emphasizes, cooperation makes sense if and only if the coalition of States that is behind it acts in response to a system failure. The diversion of the institutions in place is more advantageous than the struggle against the contemporary hegemonic powers, whether they are primary or derived legal subject of law. The BRICS is gradually becoming a necessary player in that it supports, apparently, the philosophy of the IOs. Thus, as an example, if the Gate Foundation has long ensured the financing of the R\&D sector, today, it is thanks to the proactivity of the BRICS and the financing support of Brazil and India that the WHO can continue to carry out its health mission and, even more, develop new policies. The WHO, in one of its communiqués, expresses that "for investment in the prevention and treatment of tuberculosis in low- and middle-income countries, it is almost \$ 2 billion \$) out of the \$ 8.3 billion needed in 2016 . This deficit will worsen by 2020 if current levels of funding do not increase" (http://www.who.int). Since 2011, the date of the first meeting, and so far, the action and policy of WHO are still widely recognized and praised, as if to insist on the merits of its existence. The fundamental role of the Organization is constantly being recalled and, logically, the importance of preserving its existence and functioning as a body for the management of health policies is regularly reiterated. However, the BRICS also reports its commitment to continue to contribute to the Organization's policy, developing new solutions to achieve MDG 4 (CRESWELL, 2014). In each of its Statements, the group recognizes the importance of the UN-Nations institutions but, at the same time, stresses their limit: without the action of the group, how could these institutions continue to implement strategies for the eradication of infectious diseases? The BRICS uses a de facto situation that, in itself, is synonymous with vulnerability: the management of infectious diseases at the national level is impossible. It is then by pooling their health interests, guided by an economic ambition, that BRICS members succeed in reversing the interdependence - dependence on International Organizations and big States powers to establish themselves as the power of resolving difficulties (KICKBUSCH, 2014.) 
BRICS is posed to being an unwavering innovative support to aging IOs. In 2014, the group's policy becomes more straightforward, more aggressive: the tone is set to no longer recognise the existence of the $\mathrm{WHO}$ but instead to affirm the strong undisputed role the group plays within the UN architecture. Furthermore, two events support this new policy: on the one hand, holding the first Meeting of the Science, Technology and Innovation Ministers committee that shows the will of the group to be at the forefront, thus separating itself from the International Organizations. On the other hand, there has been an explosion of vaccine production worldwide. It is by positioning itself as a non-threatening actor and by implementing WHO policies that BRICS establishes its status as a legitimate entity, bordering on the accepted criteria of a legal entity. The Organization will acknowledge in a recent Statement that:

the five countries had taken important initiatives in the area of vaccine technology development and had greatly improved their national regulatory capacity (...), the results show that The BRICS group has had a major impact on the price and availability of vaccines, and this impact is largely attributable to the production of Indian vaccine manufacturers (OMS, 2016).

For the BRICS, quality seems to rhyme with quantity: in 2016, a study pointed out that Chinese researchers have created the first vaccine in the world against hepatitis E. From 2015, the BRICS will expand its field of action, setting itself up as a defender of global health crises by mentioning the serious concern that constitutes Ebola. Beyond the human and social aspect, through the recognition of its intellectual property rights, finding a vaccine against Ebola would ensure the BRICS a status of international financial and commercial leader. The structuring action of the group is the corollary of a form of normative recognition: the lever financing-of-the-policiesWHO is finally only a sesame to easily penetrate the forum of the WTO and to effectively and efficiently modify the regulation of world trade, the issue of intellectual property being a priority or, in a way, a pretext. By positioning itself as a non-threatening actor and effectively implementing WHO policies, the BRICS establishes its status as a legitimate entity. From there, it will gradually assume a place of first choice on the international scene.

\subsection{BRICS ACTION BY TRANSGRESSION THROUGH THE CREATION OF A GLOBAL LEGAL ENTITY}

The various communiqués from the BRICS Health Ministers provide three basic pieces of information for the development of our thesis: first, it is announced that the BRICS, in view of the importance of the MDGs, will actively develop the implementation of policies in these territories, notably through the establishment of Universal Health Coverage (UHC). Sectorial national politics 
and group policy are inseparable but by managing to pool their interests: the BRICS States become the leader in the field of public health. Secondly, the commitment to respect the provisions of TRIPS is reiterated, concerning the provisions on greater flexibility for developing and least developed countries (ODELL; SELL, 2006). By this second point, the BRICS presents itself as a spokesman for States in difficulty or, at least, for States not integrated into the WTO. The Organization was created in a certain way by the action of the negotiating groups. In the Uruguay Round, the cause of developing countries and LDCs was mainly championed by Cairns and the ACP (NARLIKAR, 2004). The WTO is, in a way, permeable to the actions of groups of States. Finally, it is more widely the action of the WTO and the WHO which is praised as regards the evolution of the discussions on the regulation of access to medicines. This last point then confirms the strong and unwavering link between trade and health, recognizing the viability of the BRICS health strategy to better influence the regulation of world trade (SHELEPOV, 2018).

The pathway of the BRICS consists in the development of a triple sectorial legal policy modeled on the requirements of the WHO and on its own national interests: using the fuzzy law, or right of definition, the BRICS will strengthen its commitment to integrating health policies into international trade practices. For instance, the WTO-WHO institutional cooperation in the field of access to drugs has evolved since the creation of BRICS: in 2001, both organizations held a Symposium on price regulation in order to enhance the access of troubled countries to drugs and in 2013 the WIPO joined them. The different topics of the Symposia dealt with the question of innovation, the warhorse of BRICS (CHAKRABORTY, 2006; DREZNER, 2015; FRASER, 2014). Beyond this inspiring action, the media notes of BRICS illustrate how their actions and the G20 action are in synergy, making the UN-Nations group a mere site for holding a meeting, as if the modes to achieve a legal entity should change as well (GAUTIER, 2014). Somehow, it is as if BRICS would be trying to create a form of global legal entity playing, both on the internal and external aspects through the multiplication of meetings in international organizations. By optimizing the use of soft law through the manipulation of fuzzy law, the BRICS will contribute to the creation of a real right of participation, or else right of elaboration or definition, where each State member can defend its interests without having to submit the will of others. The BRICS does not constrain, it brings together. Far from the classic strategy of subordination of State interests, the BRICS acts according to a dynamic of sharing interests while respecting the sovereignty of each. This practice ensures coherence between the development of a national sectorial policy and the construction of a legal policy of the group (GRAY; MURPHY, 2013; GRUBER, 2000). 


\section{THE OPTIMIZATION OF SOFT LAW: POIÈSISOF NORMATIVITY BY THE BRICS ACTION}

The WTO, before being a normative and jurisdictional body, is a forum of negotiation. The $\mathrm{WHO}$, by the way, is also based on the negotiation - law-making mechanism. It is therefore by definition that these Organizations are led to use soft law, a kind of rule of attenuated authority describing behaviours that its author wishes to see adopted by its addressees, in order to coordinate the actions of (States) in society and to promote their cooperation (NYE, 1990; CHATZISTAVROU, 2005). Soft law is a different constraint from hard law and if IOs resort to this type of norms, it is above all to avoid jeopardizing State sovereignty (CULOT, 2005). The BRICS, by its structure, out of bounds of the definition of subject of law, will resort alternatively to the use of hard law and soft law, on the one hand, because this last type of norms assures him a certain legitimacy, and, secondly, because soft law, in that it is linked to soft power, makes it possible to increase the field of competence of the BRICS, and thus its effectiveness (FOOTER, 2010).

BRICS, as a mere actor, can create a real participation and non-subordination right, which confers to soft law actions a real legal scope (ABBOTT; SNIDAL, 2000). To carry out its legally ensured power game strategy in which each member receives an equivalent space to participate in the creation of the law, BRICS will contribute to reinforce the hard law $\approx$ soft law interdependence, using a soft power avenue. It is by implementing the exceptions envisaged by the WTO and WHO that BRICS will show that hard law requires, to come true, soft power infrastructures. The actions of BRICS concerning the law, given that it is a simple implementation of conventional dispositions, illustrate that hard law and soft power (A) complement each other, and the soft power $\equiv$ soft law progression is illustrated through the orientation of the WTO judicial policy by means of the WHO sectorial policy (B).

3.1. THE HARD LAW $\equiv$ SOFT POWER COMBINATION: THE BRICS ACTION CONCERNING THE LAW, A SIMPLE IMPLEMENTATION OF CONVENTIONAL DISPOSITIONS THROUGH THE SURVEILLANCE CENTRE

In WTO law, both the Agreements on Trade in Goods, the TRIPS and the GATS contain explicit exceptions to the liberal requirements of the Organization (GAUTIER, 2014). Trade barriers are acceptable practices to the extent that they are intended to protect the consumer and that their merits are scientifically verified. Hard law can take two forms: principles to be followed or exceptions to be respected, depending on whether one is in the sphere of WHO, whose object relates to public health, or the WTO, whose business purpose must consider public health requirements. Given the same objective, the two Organizations employ different aspects that are 
complementary to this type of normativity. But the variation in the drafting of conventional standards further hampers the possibilities of guaranteeing their respect (KOHLMORGEN, 2007; KRASNER, 1982). Yet, and this is precisely what was illustrated in the case DS26: EC-Hormones, where, by appealing to the Codex, the EU has highlighted the limits of hard law. At the same time, it is the suppletive and yet essential dimension of soft law that has been focused on. Moreover, by this mention, it is the importance of the consensus mechanism that has been devoted, conferring, with strong anticipation, the added value of a governance orchestrated far from the institutional rigidity of the post-WWII system.

Considering, that Brazil is the third-largest tobacco producer and exporter country, only after China and India and ahead of Russia, and, that FIOCRUZ will take the initiative in this regard, the tobacco issue is of utmost importance for the creation of the legal and political strategies of the group (THORSTENSEN, 2012). Because the BRICS nations will finally allow for the implementation of WTO and WHO conventional norms, the integration of health policies in the world's trade law is meaningful and active. During the October 2015 meeting held in Moscow, the BRICS Health Ministers, in order to materialize the Article 5.3. of the WHO Framework Convention, and to enforce the decision FTC/COP3(7) of 2008, decided to establish, in their respective territories, Surveillance Centers or Observatories for the tobacco industry, so that measures can be taken to limit the launching and the proliferation of this kind of products. The first of the five BRICS nations to be actually engaged was Brazil, with the creation of FIOCRUZ in 2016, whose initiative was largely welcomed by the DG of the WHO. A great part of FIOCRUZ's action is to come up with judicial policies aimed to counter the action of certain nations that are heavily dependent on the tobacco industry (OMS, 2016). The Centre has, thus, elaborated a policy including judicial decisions, and is poised to confirm that, oftentimes when a national lawsuit takes place, States use the WHO Framework Convention as an excuse in order to dismiss the allegations of the industries. Apart from playing a simple influential role, BRICS greatly contributes to the international architecture from an institutional point of view: due to its intervention, it is considered both autonomous and proactive a group. Facing hard law that is often considered vital, and soft law envisaged as a necessary mode to enforce conventional law, it seems that BRICS has opted again for the third way, using soft power as a transition between these two aspects of the normativity.

\subsection{THE SOFT POWER $\equiv$ SOFT LAWPROGRESSION: ORIENTING THE WTO JUDICIAL POLICY BY USING THE WHO SECTORIAL POLICY IN A BRICS FASHION}

Rather than opting for the median jurisdictional confrontation of the DSB, the BRICS prefers an approach of misappropriation of legal mechanisms in the strict sense of the term. The 
members of the group will play the subtle nuance between will and interests, constituting a third party in certain disputes of the DSB, thus giving substance to their strategy of creating a real right of participation. Indeed, if, because it is not a subject of law, the participation of the BRICS as such in the dispute settlement mechanisms of the WTO is impossible, it remains that its participation fragmented, in the strict framework posed by third-party status, constitutes a means of action. The creation of supervisory bodies for the tobacco industry thus constitutes a bridge between hard law, with undeniable obligation, and soft law, which is illustrated by the various communications and documents published by the BRICS to notify his will. This institutional gateway is in itself an act of soft power, focused both on the implementation of the provisions of hard law and a directed use of soft law acts.

By the creation of FIOCRUZ, in Brazil, after the meeting of ministers of health in Moscow, the issue of tobacco and related industrial policies, because they threaten compliance with Article 5.3. of the WHO Convention, constitute the basis for the development of a WTO-oriented judicial policy (RICUPERO et. al, 2012). In 2010, a few years before the creation of FIOCRUZ, the Clove Cigarettes dispute between the United States and Indonesia opened. Brazil reserved its thirdparty rights as soon as the panel was formed. By that time, he was the only BRICS country to have come forward. Its jurisdictional approach cannot then be interpreted as a guarantee of an informal representativeness of the interests of the group, but only as the expression of own State interests; of his will. Considering, on the other hand, that Brazil is the third-largest producer and exporter of tobacco after China and India, and before Russia, and on the other hand, that it will be the initiative FIOCRUZ, the tobacco issue is of considerable importance in the elaboration of the group's legal, political and health strategies. If the BRICS has been directly involved in setting WHO's sectorial policy, it may be that, as a decisive player in the tobacco market, the practice of policy control industrialists in this field would help them gain legitimacy: by integrating and implementing WHO's health policy, the Group stands as an example to be followed, and not as a threat, thus damaging the pioneering hegemonic in place.

Where Krasner saw irreducible tensions power games, soft device by Keohane and Nye can understand that if the BRICS manages to win, it is by diverting the mechanisms of struggle: the law is no longer useful from now on to guarantee the application of the norms but it serves to legitimize new geopolitical behaviours. In 2010, i.e. some years before the creation of FIOCRUZ, the Clove Cigarettes Dispute between the United States and Indonesia took place. Brazil has reserved its rights as a third party ever since the special group was set up. At that time, it was the only BRICS country to have spoken out. Its jurisdictional approach cannot be interpreted as a token of an informal representation of the group's interests, but only as an expression of its own interests. After the creation of FIOCRUZ, as the tobacco issues and the related industrial policies 
might threaten the enforcement of Article 5.3. of the WHO Convention, they become the basis of the development of a judicial policy implemented within the WTO framework, given that BRICS prefers a diversion of jurisdictional mechanisms. The most flagrant case of manipulation of judicial policies has recently been illustrated with Australia. In 2011, the country adopted a plain packaging law; the reaction of Imperial Tobacco Australia, British American Tobacco Australia and Philip Morris Limited was not long in coming and in 2012 Australia had to answer for its legislation in a national court. More surprisingly, the WTO has had to decide on the legal-political consequences of this national dispute: since 2012, 5 complaints have been lodged against Australia with the OSD on the grounds that its legislation violates Articles 1, 1: 1, 2: 1, 3: 1, 15, 16, 20 and 27 of the TRIPS Agreement and Articles 2.1 and 2.2 of the TBT Agreement, the WTO treaty provisions recognizing public health as a fundamental element in the development of world trade law. Even more surprisingly, Brazil, Russia, India and China constituted third parties in the said disputes and yet only Brazil presented its arguments only in the context of DS 434 and 458, arguing in the one and the other case that:

in order to meet the substantive requirements of Article 6.2 of the DSU, the request for the establishment of a panel must identify the measures targeted in the dispute and contain a brief summary of the legal basis of the claims + add on the reasoning of the parties (DS434 - 15, §3.21\& 458-18, §3.23).

The concordance between the opening of the consultations of these disputes with the WTO, the reservation of the rights of the third parties of the BRICS, the decision of the Australian judge, and the creation of the FIOCRUZ enjoins to conclude to a strategy of judicial policy on the part BRICS. By acting as guarantor of the FIOCRUZ program and by becoming a third party in disputes relating to the tobacco issue, the BRICS - the median manifestation of Brazil - ensures the implementation of the WHO Framework Convention within the World Health Organization. Indeed, although the rights of third parties are limited by its argument, Brazil makes it clear that its objective is to ensure the continued existence of FIOCRUZ, the DSB being used as a judicial mechanism to guarantee the project. Thus, the WHO-linked soft power structure FIOCRUZ provides the basis for Brazil's soft law claims under the WTO dispute settlement mechanism.

\section{CONCLUSION}

If the legal subjects of international law are no longer the only ones capable of claiming a hegemonic practice, the fact remains that, in order to form the basis of a paradigmatic reflection on the future of the BRICS, this must be accompanied by a legal approach. However, this aspect 
has often been abandoned in favor of a strictly political analysis of the group's action. While it is undeniable that the BRICS is revolutionizing governance through the redefinition of the fundamental concept of power, it is in international law that its impact is most striking, as the group acts as a catalyst of normativity. The creation of soft power structures ensures the implementation of hard law, which enables to guarantee the scope of the group's soft law actions. Likewise, BRICS challenge IOs efficiency: it highlights their inability to also use soft power to ensure the enforcement of its own conventional regulations. Using this strategy BRICS becomes a necessary actor for the survival of IOs and, paradoxically, the biggest threat for their future. Thus, in view of the question of how the BRICS participates in the moralization of capitalism, I have considered the hypothesis of a BRICS new form of hegemony, in the sense that the forms of cooperation promoted by the group are innovative and not corresponding to any concept currently in force while the coalition is dominating, step by step, the current global order. BRICS presents itself as a guide to the international society, but at the same time, each member insists on maintaining control over its national resources and the area of the world that it dominates.

BRICS made a genuine redefinition of the fundamental concept of power which revolutionized governance (ALDRIGHI, 2009; BORBA CASELA, 2011). Since then, power is defined through the triptych: financial sovereignty - strong and solid technological development sectorial economy. BRICS practice also leads to a redefinition of power plays (HURREL, 2009). So, if state-centrism is no longer current, it is a fact, however, the role of the State remains central: it was only the definition of the State that changed, insofar as it is now exclusively linked to that of capitalism. Since the subprime crisis, it has been about making capitalism moral, clean and transparent. Now, considering that this is the new objective of the international society, this means that until then capitalism was dirty, obscure and immoral. Therefore, beyond the redefinition of forms of governance, BRICS cooperation forms part of a new era; an era dedicated to the purification of capitalism. And if the challenge seems to be of Marxist inspiration, it is not, however, incompatible with today's neoliberal practice: ambition is, in effect, to convert capitalism into morality. It is not about destroying it but all purity is cruelty, and in the present case purifying -capitalism would be to suppress the mechanism of surplus-value. The BRICS tries to respond to the demand to cleanse capitalism. Neoliberalism is moving towards the end and the hypotheses of post-hegemony are only partially illuminating. BRICS cooperation presents itself as the 3rd long-awaited path: far from neoliberalism and socialism, the BRICS incarnates the original will that animated the creators of this famous "third world". Because, in fact, at the beginning of the Cold War, the Third World was not the expression of a stigmatization, reflecting rather the will to 
create an alternative to the two blocs. The third world was, therefore, the incarnation of the third possible way.

To think of the BRICS, which has questioned the whole architecture of the international society since WWII, is, therefore, to think of the exit of an East-West / North-South sclerosing opposition. By recognizing the fundamental existence of classical IOs but by substituting their normative framework on its own, the BRICS demonstrates their inefficiency. Therefore, there is a BRICS normativity built on a triple logic interpretation - explanation - modification of the law in order to ensure its domination of the political game. The law is no longer a guarantee of the current world order: it becomes an instrument at the service of a real and deep change. Although the BRICS was initially formed to ensure "a fairer world trade", the expansion of its scope has continued since the Yekaterinburg and Fortaleza Summits, making the question of the regulation of health policies an influencing tool and /or argument to curb WTO Law. It is by misappropriating the median WTO law that BRICS succeeds in redefining normativity. In response to the ontological legal crisis, classical IOs are the most endangered and tend to be imperialistic, going beyond the original function of the hegemon-guide to make it a hegemon-dominus. By proposing alternatives of governance oriented using health policies and making innovative use of WTO law, the BRICS revives with the first conception of the hegemon, a guide working for the common good, without losing sight of the realization of its own interests.

Highlighting the complementarity between the approaches of Keohane and Krasner, we can thus consider that the counter-multilateralism of Keohane, in that he interprets the mechanisms of State coalition as consubstantial to the realization of a true cooperation, brings a track of answer to the vision of Krasner, which consists of an explanation of the State of the median international relations the power games. The BRICS have made their State weakness a decisive asset and although the legality of the instruments used is questionable, the fact remains that their use allows the group to upset the criteria of normativity accepted until then. So, because BRICS assertion of hegemonic power involves cooperation, and to mark the semantic difference from the overly connoted concept of hegemon, we propose to now call the BRICS Hegemon Operationis, posing the hypothesis that this new form of regulating international relations would be the way to make capitalism moral.

* Artigo recebido em 11 de agosto de 2019, aprovado em 13 de novembro de 2019. 


\section{REFERENCES ${ }^{2}$}

ABBOTT, K.; SNIDAL, D. Hard and Soft law in International Governance. International Organization, Vol.54, N³, 2000.

ACHARYA, S. et al. BRICS and global health. Bulletin of World Health Organization, Vol. 92, $\mathrm{N}^{\circ} 6$, 2014.

ALDRIGHI, D. Cooperation and coordination among BRICS countries: potential and constraints. Brasil, Fundação Instituto de Pesquisas Economicas, 2009.

BARTSCH, S. The Global Fund to Fight AIDS, Tuberculosis and Malaria. In Bartsch et al. (eds). Global Health Governance and the Fight Against HIV/AIDS. Basingstoke: Palgrave Macmillan. 2007.

BORBA CASELA, P. BRICS: Brasil, Russia, India, China e Africa do Sul. Brasil, Atlas - Paperback. 2011.

CASHWELL, A. et al. BRICS in the response to neglected tropical diseases. Bulletin of the World Health Organization, Vol. 92, Nº6, 2014.

CHAKRABORTY, D.; SENGUPTA, D. IBSAC (India, Brazil, South Africa, China): A Potential Developing Country Coalition in WTO Negotiations. Centre de Sciences Humaines Occasional Paper No. 18. December 18, 2006. Available at SSRN: https://ssrn.com/abstract=1626717.

CHATZISTAVROU, F. L'usage du soft lawdans le système juridique international et ses implications sémantiques et pratiques sur la notion de règle de droit. Le Portique. 2005 [On line], consulted on 13/11/2019. URL: http://leportique.revues.org/591.

CRESWELL, J. et al. "Tuberculosis in BRICS: challenges and opportunities for leadership within the post-2015 agenda." Bulletin of the World Health Organization, Vol.92, 2014.

COX, R. Gramsci, Hegemony and International Relations: An Essay in Method. Millenium Journal of International Studies, Vol. 12, N², 1983.

CULOT, H. Soft law et droit de l'OMC. Revue internationale de droit économique, vol. t. xix, 3, no. 3, 2005.

DREZNER, D. The system worked: How the world stopped another Great Depression. Oxford University Press, 2015.

FOOTER, M. The (re)turn to 'soft law' in reconciling the antinomies in WTO Law. Melbourne Journal of International Law, vol. 241, 2010.

FRASER, J. BRICS ministers join forces for access to medicines. Intellectual Property Watch, [On line] consulted in 13/11/2019, https://www.ip-watch.org/2014/05/20/brics-ministers-join-forcesfor-access-to-medicines/.

GAUTIER, L. et al. Reforming the World Health Organization: what influence do the BRICS wield?. Contemporary politics, Vol.20, №2, 2014.

\footnotetext{
${ }^{2}$ We have chosen not to deliver the exhaustive list of official BRICS documents used and refer to the website: http://www.brics.utoronto.ca/docs/.
} 
GRAY, K.; MURPHY, C. Introduction: rising powers and the future of global governance. Third World Quaterly, Vol.34, N², 2013.

GRUBER, L. Ruling the World: Power Politics and the Rise of International Institutions. Princeton, Princeton University Press, 2000.

HAGGARD, S.; SIMMONS, B. Theories of international regimes. International Organization, Vol.41, 1987.

HURRELL, A. Hegemonia, liberalism e ordem global: qual é o espaço para potencias emergentes?. In Hurrell Andrew et al (eds). Os BRICS e a ordem global. Rio de janeiro, Editora FGV, 2009.

KEOHANE, R. International Institutions and State Power: Essays in International Relations Theory, Boulder, Westview, 1989.

KEOHANE, R.; MILNER, H. (eds). Internationalization and Domestic Politics. Cambridge, Cambridge University Press, 1996.

KEOHANE, R. Power and Governance in a Partially Globalized World. London, Routledge, 2002.

KEOHANE, R.; NYE, J. Power and Interdependence. London, Pearson, 2001.

KEOHANE, R.; MORSE, J. Counter-Multilateralism and Regime Complexes. CMRev. 2013. [On line] consulted in 13/11/2019. https://pdfsecret.com/download/1-counter-multilateralism-andregime-complexes-julia-morse-and-robert-o-keohane1-abstract-

_5a3cb31dd64ab2a613558fd5_pdf

KEYLOR, W. The Twentieth Century World: An International History. Oxford University Press, 2003.

KICKBUSCH, I. BRICS? Contributions to the global health agenda. Bulletin of the World Health Organization, Vol. 92, 2014.

KINDLEBERGER, C. Dominance and Leadership in the International Economy: Exploitation, Public Goods, and Free Rides. International Studies Quarterly, 25, 2 (June), 1981.

KOHLMORGEN, L. International Governmental Organizations and Global Health Governance: The Role of the World Health Organization, World Bank, and UNAIDS. In BARTSCH et al (eds). Global Health Governance and the Fight Against HIV/AIDS. Basingstoke: Palgrave Macmillan, 2007.

KRASNER, S. Structural Conflict: The Third World Against Global Liberalism. Berkeley: University of California Press, 1985.

KRASNER, S. Structural Causes and Regime Consequences: Regime as intervening Variables. International Organization, Vol.36, N², 1982.

KRASNER, S. Rethinking the sovereign State model. Review of International Studies, Vol.27, N5, 2001.

KRASNER, S. Sharing sovereignty: New institutions for collapsed and failing States. International security, Vol. 29, №2, 2004. 
NARLIKAR, A. International trade and developing countries: bargaining coalitions in GATT and WTO. London: Routledge, 2004.

NOGUEIRA, J. P. Os BRICS e as mudanças na ordem internacional. In PIMENTEL et al. (eds.), O Brasil, os BRICS e a Agenda Internacional. Brasilia, FUNAG, 2012.

NYE, J. Soft Power, Foreign Policy, N80, 1990.

ODELL, J. S.; SELL, S. Reframing the issue: the WTO coalition on intellectual property and public health, 2001. In ODELL, Negotiating trade: Developing countries in the WTO and NAFTA. New York: Cambridge University Press, 2006.

OMS. Investir pour réduire l'impact mondial des maladies tropicales négligées. OMS Troisième Rapport. 2015.

OMS. Directives pour l'application de l'article 5.3 de la Convention-cadre de l'OMS pour la lutte antitabac sur la protection des politiques de santé publique en matière de lutte antitabac face aux intérêts commerciaux et autres de l'industrie du tabac. 2016.

PEREZ, O. Fuzzy Law: A Theory of Quasi-Legal Systems. Canadian Journal of Law \& Jurisprudence, Vol.28, №2, 2015.

RICUPERO, R.; PIMENTEL, J.; AMARAL, S. O Brasil, os BRICS e a agenda internacional. Brasilia: Fundaçao Alexandre de Gusmao, 2012.

SHELEPOV, A. BRICS engagement with international institutions for better governance. BRICS and Global Governance. London, Routledge, 2018.

SHRADDHA, N. The Rise of BRICS- A Multipolar World?, Jawaharlal Nehru University, New Delhi, Asia-Pacific ISA Conference Hong Kong- 25-27 of June, 2016.

SILVA, J. B. et al. BRICS cooperation in strategic health projects. Bulletin of World Health Organization, 2014.

THORSTENSEN, V.; MACHADO OLIVEIRA, I. T. Os BRICS na OMC: políticas comerciais comparadas de Brasil, Rússia, Índia e África do Sul. Brasília, Ipea, 2012.

WEBB, M. C.; KRASNER, S. Hegemonic Stability Theory: An Empirical Assessment. Review of International Studies, vol. 15, no. 2, 1989, pp. 183-198.

YU, P. Access to medicines, BRICS alliances, and collective action. American Journal of Law and Medicine, Vol. 34, 2008. 